\title{
A Study of Extra Marital Relations in Urdu Dramas: A Qualitative Analysis
}

\author{
Yasar Arafat \\ Nauman Sial \\ \& \\ Abid Zafar \\ Media and Communication Studies \\ International Islamic University Islamabad (IIUI)
}

\begin{abstract}
Couple interactions in Urdu drama serials were analyzed to investigate whether healthy (positive) or unhealthy (negative) couple communication is portrayed. It is point of discussion that plots of the contemporary Urdu televise dramas in Pakistan is depicting more extramarital relations. Through narrative structure analysis, the current study revealed that drama serials start with a family and then a quarrel arises between married couple. At that point, a protagonist enters in the scene which also becomes as catalyst in making separation between the married spouses. The bad and harsh attitude of the husband appears to be the enough reason to bend toward extramarital relation. Divorce seems to be the only solution in case of incompatible relations between the spouses. It is apparent that these dramas are promoting extramarital relations in positive ways. The current bombardment of such issues by electronic media seems to be trying to legitimize the illegitimate relation. The analysis depict that televise Urdu dramas of Pakistan are promoting more negative interactions among the couples.
\end{abstract}

Keywords: Urdu Drama, Extra Marital Relationship, Family Values, Marriage, Divorce.

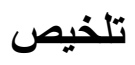

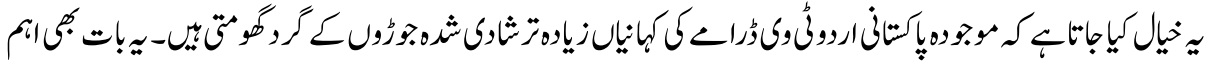

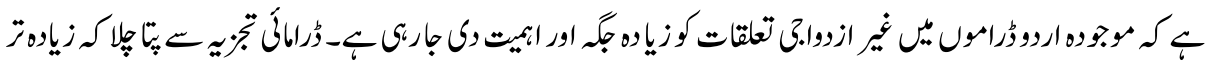

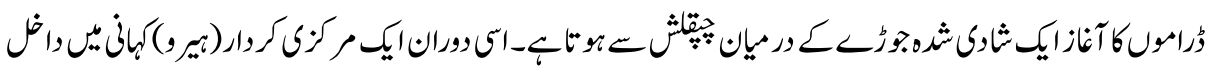

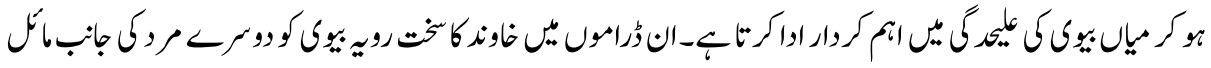

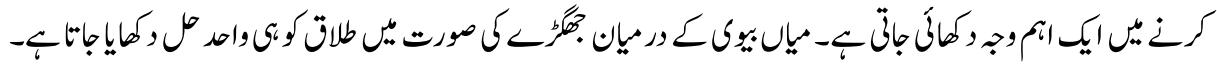

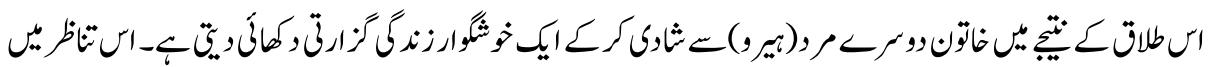

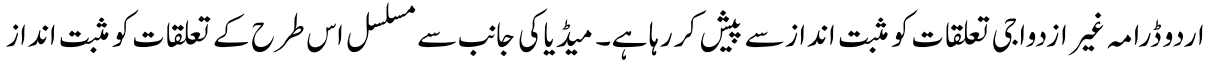




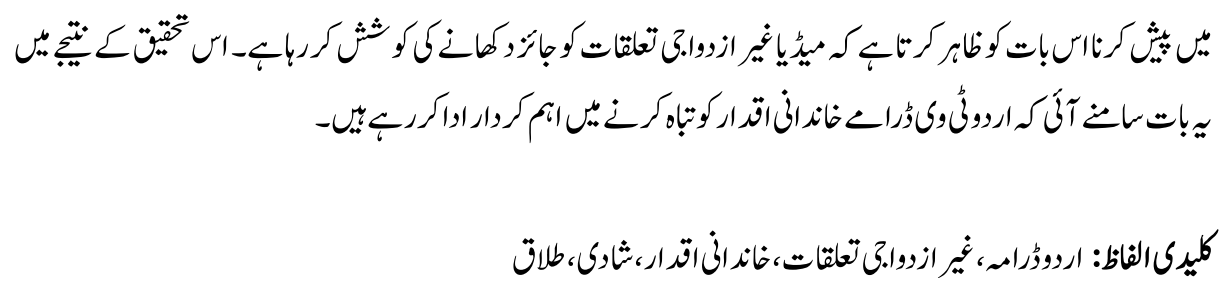

\section{Introduction}

One of the basic purposes of the media is to entertain, but along with entertainment the entertaining program should also have some elements of learning or edification in it. On the other hand, the program should also address some social and ethical message in it. The women population is almost equal to men in Pakistan and most of the women do use media for entertainment purposes. In addition, most of the entertaining segment for the women is Urdu drama (Ahmed, 2012). Drama is the most solid form in which art can recreate human situation. The word 'Drama' is abstracted from the Greek word 'Draw' which means 'to act' (Birch, 2014). According to Aristotle, there are six main components of the drama which include plot, character, thought, diction (language), melody and spectacle i.e. visual elements(Birch, 2018). The dramatic genres usually include tragedy, comedy, tragi-comedy and melodrama (Iwuchukwu, 2008).

The history of television in Pakistan was started from 1964. Right from the beginning, drama became the essential part of the Pakistan Television (PTV). After the establishment of first television station in Lahore, PTV drama producers focused on the social issues of the society. In this way, important segments of the society were highlighted through Urdu dramas. Since 1964, PTV has produced thousands of Urdu dramas. Other than the number, one thing is sure that most of the dominated plots of these Urdu dramas were about the social issues. Among these social issues domestic problems, psychological issue, crime and punishment, feudal system and its negative effects, problems of youth, unethical use of powers by the powerful persons were among the leading social issues which were discussed in these dramas (Rehman, Arafat, Sial, \& Shah, 2019; Tahir, 2009). These drama serials also showed some positive and healthy relationship among the married spouses. The amalgamation of family was the ultimate target of the earlier drama serials. Although, modern television families deal with more complex, personal and relational crises compared to television families of the past. But the past television families usually communicated well with each other (Rehman et al., 2019).

The real change in Urdu drama was recognized after 1990, when private channels were also allowed to on air their transmission. Some of the critique mentioned that first twenty five years, the producer, directors and writers worked with passion but after 1990, the 
places of passion was replaced by materialism. Materialism and commercialism badly affected the Pakistan Television dramas. The marathon of competition with private channels badly damaged the performance of the Pakistani television drama. The passion or interest of the producers was replaced by rating and maximizing the profit. Producer, writer and actors were all under the influence of commercialism. The social problems of the society are being ignored and rating seems to be the ultimate objective through controversial plots of the drama (Ahmed, 2005).

It is highly needed to investigate that what sort of content are being disseminated in the name of entertainment. The portrayal of family values and relationship among the spouses is of utmost importance. Along with character, the plot of the drama is also very important, sometime single scene and dialogues do not depict the whole picture so plot will also be helpful in exploring the real message from these dramas. In the last few years, Urdu drama plot are showing more extramarital relations. The seillicit relations are not only the basic theme but also these relations are molded in such forms, which create new hero and new villain. The depiction of extramarital relations in Pakistani Urdu dramas is one of the hot debates for last few years (Siddique, 2016). The depiction of extramarital relation is not only the problem but how these extramarital relations are depicted is another problem. In the past, wedding and a joyful life were once the ending to a drama of self-realization but now the wedding promise mark the beginning of a torturous process of misunderstandings with disloyalty lurk around every corner (Haider \& Siddique, 2015). In contemporary society, where divorce rate is increasing day by day, it is the need of the time to have great in-depth look of Urdu televise drama (Siddique, 2016).

The quarrel between the spouses appears to be the leading trend in the last decade or so. Married spouses are depicted to find their love outside the married relation even after the married life. Married spouses are depicted as antagonist to each other and their hero or heroine is shown outside the marriage relation. In the past, the leading trend in the television dramas of Pakistan was social issues. Further problematic is that modern Urdu dramas are presenting such contents that are in conflict with the cultural and family values of Pakistan. In the name of modern entertainment, even the respectable relationships are ruined. In a good number of the dramas where a male falls in love with his daughter's friend or a girl starts having an affair with her brother-in-law, and uses all sorts of ploys and unfair means to make him/her life-partner. These are only a few examples of all the irrationality and amusement is being achieved through controversial themes of dramas like Mera Saaein, Maat, Kitni Girhen Baqi Hain, Tair-e-Lahoti, Mujhe Khuda Pe Yaqeen Hai, Maane Na Yeh Dil and the list can go on and on (Wali, 2014). Overall it is perceived that television is portraying unhealthy relationship between the spouses. Most of the communication between the couple is shown as aggressive and harsh; similarly the relation between couple is shown as ignoring, evading and withdrawing from each other. 
Üçer (2013)argued about the creating of the 'reality' and 'virtual reality' concepts through television screen by the example of a very high rated Turkish soap opera The Valley of the Wolves. The study examined the central theme of the soap opera The Valley of the Wolves on the cultural and sociological basis. Ucer typically focused to recognize how media, mainly the 'Televise Media', maneuver people's perception of the reality through 'fictive characters' and how a new reality is assembled in social realization. The main purpose of the study was to try to reveal how audiences were influenced by the soap operas fictive characters and the happening that take place on each episode. The study revealed that people were confused and they lost track of the reality: they think what happened on the episodes were real because there were similarities with the real incidents. Unexplained real events were 'explained' or at least 'clarified' to some extent. However, there was a new reality created through the soap opera and its fictive characters. This phenomenon could also be named as 'virtual reality' production through media. The director of the soap opera explained his view about this drama in this way: "I like dream and I sell dreams." In this article, the director Osman Sinav affirmed "I like to dream and sell dreams, and I do not care about the speculations," and he refused the assumption about the reality production of the series.

Taylor (1989) studied the changing image of the family on prime-time television from the 1950's through the 1980's which provides a clear example of the ideological twists and turns of network television. By the middle of the 1970's, the image of the family was neither all white nor all middle class, and domestic life was no longer an utopia; instead, the family was depicted as a source of conflict and struggle as well as comfort and love.

\section{Review of Literature}

Married couples in dramas or soap operas can be portrayed as positive where healthy communication is depicted between them. On the other hand, couples can be depicted as negative where unhealthy communication is depicted between them. Most of the unhealthy relations are presented to show that family is in turmoil and the main objective is to resolve the conflict in the family. Comstock \& Strzyzewski (1990) indicated that modern families on television are consistently shown having lackness to manage day to day life and show a hostile relation towards one another. Married spouses are often shown as avoiding discussing involving relational concern with each other. The study also shows a negative communication is depicted mostly between the married spouses in soap operas. Douglas \& Olson (1995) argued regarding comparing comedies from 1950 through 1990 that working class families portrayed relationships that were relatively closed, conflicting, and/or unsatisfying. These families had the highest levels of distress, fathers were seen as inept, and spousal relations were seen as negative. These findings reinforce the relative desirability of middle class norms in families. 
Al Helal (2013) study on Indian drama serials broadcasted in Bangladesh also found a negative relation and unhealthy communication between the spouses. The study also examined the extramarital relations that were depicted in Indian drama serials. For example, in drama serial 'Keya Hua Tera Wada' hero was shown to have illegal relations with other girl despite having three children. These extramarital relations were depicted in such gentle way to the viewers as it seemed that extramarital relation is compulsory ingredient for the family. Such depiction may easily influence the drama viewers. The research revealed that $23 \%$ of Bangladeshi respondents do believe that like pre-marital relations, Indian drama serials were also responsible for extramarital relations. Helal argued that the key problem in the drama was that community had lost path of the realism and they considered that what happened in the drama was real and these viewers created a virtual world in their mind. Fiction and fantasy do play a central role in creating virtual world and these two elements further show their strength in affecting the minds of the people.

Modleski (1979) explained that it looks significant to distinguish that play or drama serials contribute to establish the dominance of the family not by depicting an ideal family, but by showing a family in constant turmoil and pleasing to the spectator to be understanding and tolerant of the many evils which go on inside that family. Drama serials or soap opera normally introduce those issues which can be tolerated and ultimately pardon. Normally drama or soap opera stories revolves around the problems like, physical cruelty, alcoholism, abortion, extramarital and premarital sex, divorce and physical brutality. Other issues which have the power to blow up the family structure are avoided or simply ignored. For example, the issue of homosexuality is such kind of problem which may demolish the basic structure of the family, instead of temporarily disrupting it. Thoughts that are expelled from the main media or appeared in negative way on the media have little legitimacy. Such thoughts or ideas are not considered as acceptable ideas, and considered outside the range of tolerable ideas. The ideological influence of media could be seen in the absences and exclusions just as much as in the content of the messages.

Dainow (2014) critically evaluated the work of Adorno \& Horkheimer. Both Adorno \& Horkheimer were of the view that that culture industry does not produce anything worthwhile. All films, magazines and radio shows are "rubbish", and intended to be rubbish: "The truth that they are just business is made into an ideology in order to justify the rubbish they deliberately produce."People are no longer individuals, but mere "pseudo individuals." They are now merely centers where the general tendencies meet. Mass culture has made the individual "fictitious" (p. 2).

Zare (2001) analyzed three films and their messages. In her study, she concluded that married spouses and sex lives have no constructive emotional intensity. Films and drama 
serials do focus on two attracted people conduct a market test: is this new person good enough to risk a fling? Become a life partner? Or just serve as a pleasant distraction. Zare's study concluded that drama stories or films are "cheating" genre and these movies are showing false path to the audience. Instead of showing real marriage benefits mostly movies cultivate the super ficial pleasure of adultery.

Allen (1995)explained that even in advance countries like US, Great Britain, and Australia the soap opera or drama serials do not broadcast a specific ideological message. To attract the audience, the media producers frequently try to make drama plot current and interesting. In this war of grabbing attention of the viewer, media managers introduce such drama themes or plots which have social or moral controversial issues. Plays or drama serials regularly present an acceptable forum for the airing of controversial problems than more determinant form of television soap opera or drama serials. Dramas form as vehicles for selling audience to advertiser. The attention of the serials is to serve more advertisers, producer, sponsor, and less attention is paid to audience of the serials. Basic interest of the drama producers is to work for the interest of those who are making these serials.

Brown \& Singhal (1993)focused on the ethical problem connected with the use of entertainment television for pro social development. As television viewers grow, entertainment television is speedily substituting educational television. In India, television started just to educate the society, but with the passage of time entertainment television threw out educational programs. Instead of focusing more on pro social program, television turned toward grabbing the attention of the audience. This gave birth to mix kind of content for the television audience including antisocial program. Hence researcher started focusing on the antisocial effect of these television programs. Study indicates four types of research strains which seem to be associated with antisocial television effects. First, the destructive effects of television violence, secondly the effects of advertising inaccurate health-related content on television, thirdly, the representation of negative descriptions of children and women on television, lastly the unrealistic portrayal of interpersonal and social relationship on television.

Prisyazhnyuk \& Zilova (2014) argued that media discourse has an array of techniques to generate emotional haze and promote certain values. In many cases 'new media-specific values' compete or even come into conflict with national values. It must also be declared that the alteration of values, which may be assumed the trend of the time, is initiated by the media. Research scholars talk about alteration plus wear and tear of fundamental values, which grow from the projection of 'new' values. The most helpless crowd in that respect is youth. The evidence strengthens the fact that anti-values do exist in media content. The study of two hundred British and Russian media content depicted that antivalues exist in media, while they were masked as values in the perspective of media- 
saturated reality. Also, the contemporary media always tries to create new values to grab the attention of the young people. Not only new values are created for youngster but also media distort existing values. Unfortunately intolerance, perversion, immorality and foul language are considered as freedom, free speech, independence, and maturity. In UK and Russia, popular reality shows, which are quite famous, are promoting this kind of philosophy.

Johnson \& Holmes (2009)aimed to highlight possible relationship behaviors that viewers might learn from watching romantic movies to suggest how these learned behaviors can be detrimental for viewers. Johnson and Holmes separated each relational situation into both positive and negative categories such as kissing, hugging, loyalty, cheating, and deception. Results indicated 82 incidents of deception and 33 incidences of cheating, which Johnson and Holmes suggested could influence viewers to question the good intentions of others and to believe that their actions do not have consequences. Johnson and Holmes also noted that in all incidents of affection, only a select few were between married couples, most of whom were either unhappy or implied happiness but did little to show it. Johnson and Holmes suggested that portraying marriage in such a way leads viewers "to see marriage and romance as disparate entities and with affection between married couples as an exception instead of the norm." This suggests how inaccurate media portrayals have the potential to lead viewers to perceive society in a way that is not factual. While this content analysis suggested possible relationship behaviors that can be gleaned from romantic movies, it is unable to determine what these behaviors could mean for an individual's future relationships. Further study is needed to determine what, if any, causality is possible.

Chong \& Ferrara (2009)examined the relationship between divorce rate and the depiction of excessive divorce plot in Brazilian soap operas. The study was conducted in Brazil because divorce rates had increased rather dramatically in the last three decades, in spite of the stigma traditionally associated with divorce. It was estimated that divorce rates in Brazil increased from 3.30 per 100 marriages in 1984 to 17.7 in 2002 . The study proposed the hypothesis that the spread of television and the type of values and lifestyles portrayed on television may have contributed to the increase in divorce rates. In order to gauge the extent to which these values may have shaped individual attitudes towards marital dissolution, the researchers performed content analysis on the most popular novelas aired by Rede Globo since the start of its operations. Chong and Ferrara coded all the 7 p.m. and 8 p.m. novelas from 1965 to 2004 and recorded two variables for the main female character of each i.e. whether she was separated or divorced, and whether she was unfaithful to her partner. The study revealed that the prevalence of extramarital relationships was relatively high and constant over time. Between the mid-1960's and the mid-1980's, already about 30percent of the main female characters displayed on television were unfaithful to their partners. This percentage declined to around 20 percent 
from the mid-1980's to the mid-1990's, to increase again above 30 percent in the following decade. These characters were therefore somewhat at odds with traditional models of 'faithful wives.' Chong and Ferrara argued that media programs have the potential of targeting specific groups at low cost and may be employed as a public policy tool.

\section{Research Questions}

RQ1:How the important characters are involved in extramarital relations that are being depicted in Urdu dramas?

RQ2: Is the portrayal of Urdu dramas trying to socially legitimate the extramarital relations?

\section{Theoretical Framework}

Social construction of reality is applied to explain how media is disseminating such message which is contradictory with the Pakistani social and family values. Berger and Luckmann (1966) floated this idea of the social construction of reality which states that realism is subjective and is created generally. The notion of the social construction of reality is not to say that things in our social world are not real. They are, but they are constructed. Social constructions that we often take for granted. We have built them for our imaginations. This is particularly applicable to social institutions, marriage, education, the economy come to mind. Think of some more social constructions i.e. race, gender, and religion. The social construction of reality is part and parcel to the process of socialization itself. It is in our socialization process that we learn what to consider real, important, valuable and necessary(Berger \& Luckmann, 1991).

\section{Methodology}

Pakistani televised prime time Urdu dramas have been qualitatively analyzed in this study. A narrative structure analysis has been used as a method of research design to study the plot of the dramas and the relations of the spouses in these dramas. Narrative structure, a literary element, is generally described as the structural framework that underlies the order and manner in which a narrative is presented to a reader, listener, or viewer. The narrative text structures are the plot and the setting. Generally, the narrative structure of any work be it a film, play, or novel, contains a plot, theme, and resolution. It can also be divided into three sections, which are together referred to as the three-act structure i.e. setup, conflict, and resolution. The setup (act one) is where all of the main characters and their basic situations are introduced, and contains the primary level of characterization (exploring the character's backgrounds and 
personalities). A problem is also introduced, which is what drives the story forward. The second act, the conflict, is the bulk of the story, and begins when the inciting incident (or catalyst) sets things into motion. This is the part of the story where the characters go through major changes in their lives as a result of what is happening; this can be referred to as the character arc, or character development. The third act, or resolution, is when the problem in the story boils over, forcing the characters to confront it, allowing all the elements of the story to come together and inevitably leading to the ending (Bordwell, 2008).

\section{Population and Selection of Sample Dramas}

The population for this study is the Urdu Drama telecasted by the private television channels of Pakistan during the prime time. From out of many private television channels, Hum Television has been selected for this purpose. The dramas which were on aired during the trimester of January, February and March 2016 have been chosen.The time slot of prime time i.e. 8:00 pm to 9:00 pm has been selected. The sample size for this study is two drama serials in which extramarital relations were prominent. The two drama serials i.e. Pakeeza and Mann Mayal have been selected for this purpose.

\section{Pakeeza (Urdu Drama)}

\section{Background of the Drama}

Urdu Drama serial Pakeeza was directed by Misbah Khalid. The writer of the drama was Bushra Ansari. The drama was produced by the Moomal Entertainment. Pakeeza was based on family problems and it was telecasted from Hum TV on every Thursday. The drama was on aired in the prime time i.e. from $8.00 \mathrm{pm}$ to $9.00 \mathrm{pm}$. The drama was consisted of twenty eight episodes. The first episode of Pakeeza was telecasted on February 11, 2016 and the last episode of this serial was broadcasted on August 25, 2016. Aly Khan, Aamina Sheikh, Adnan Siddiqui and Angeline Malikwere included in the main cast of this drama(Ali, 2016; Farooq, 2016; Khan, 2016). Pakeeza was having many characters, but as more concerned of the study is about the extramarital relation, so discussion will be made only about concerned characters.

\section{The Setup (Act One)}

Pakeeza (Aamina Sheikh) is being depicted as wife and also an artist who is working in art gallery. Her paintings are excellent and also she is a famous painter who wins many awards and media also gives her prominent coverage because of her painting talent. Her husband name is Jibran who is working in a bank. Jibran is depicted as a very harsh person. Jibran always insult his wife Pakeeza because he thinks that women should be 
treated like this. He developed this attitude because of his mother who had left him during his childhood. Jibran is depicted in dual role toward females. On one side he doesn't respect his wife and maltreat her but on the other side, his attitude is totally changed towards his daughter Kiran. Jibran and Pakeeza both have a young daughter Kiran who is also annoyed by her father's attitude with her mother. Jibran and Pakeeza both are not living in good relationship. Both love their daughter and in fact their relation is only going on because of their daughter Kiran.

Naima and Azeem (Adnan Siddiqui) both are shown as colleagues and also friends of Pakeeza. Naima is also the sister of Jibran. Right from the beginning, it is being shown that Azeem is having interest in Pakeeza. Even before the marriage of Pakeeza, Azeem loved her but he was unable to express his love to Pakeeza. For this reason, Azeem didn't marry yet. He also knows that Jibran is harshly treating to Pakeeza and also beats her. Azeem always asks to Pakeeza to resist against the torture of her husband. Azeem always gives advice to Pakeeza to untie her marriage relationship with Jibran. Azeem not only have sympathy with Pakeeza but he also loves her and he is ready to adopt Pakeeza.

\begin{tabular}{|l|l|}
\hline Character's Name & Character's Explanation \\
\hline Pakeeza & Jibran's wife and also working in art gallery \\
\hline Jibran & Harsh and cruel husband of Pakeeza \\
\hline Naima & Sister of Jibran and also the colleague of Pakeeza in art gallery \\
\hline Azeem & Colleague of Pakeeza and also loves her \\
\hline Kiran & Daughter of Pakeeza and Jibran \\
\hline
\end{tabular}

\section{The Conflict (Second Act)}

Jibran continues maltreatment with his wife. His attitude doesn't change with her. On the other hand, Azeem who is colleague of Pakeeza shows his support and sympathy towards her. He finally tells her that he has fallen in love with Pakeeza. He always tries to assure Pakeeza that she is not living with a proper man and her husband is cruel. Most of the time,Azeem tries to realize Pakeeza that her husband is cruel and she could attain much higher place as an artist if her life would be settle down. But Pakeeza doesn't respond to Azeem positively. She always used to say Azeem that her daughter's life is most important for her than anything else. On the whole, Pakeeza doesn't want to break up her marriage relation with her husband due toher daughter Kiran. Naima, who is sister of Jibran, also comes to know that Azeem has fallen in love with Pakeeza. Naima also thinks that her brother is not a proper man for Pakeeza.Naima also used to give advice to Pakeeza that she must live a loveful life with Azeem and untie her marriage relation with Jibran. Pakeeza also knows that Jibran is a cruel and psycho person and also Azeem loves her a lot. But just for the sake of her daughter, she is not ready to leave her relationship. 


\section{Resolution (Third Act)}

Drama takes twist when one day Jibran during quarrel with his wife Pakeeza pronounces three divorces. In this way, divorce happens between Pakeeza and Jibran. Again, just for the sake of her daughter, Pakeeza decides to live with Jibran. Pakeeza doesn't tell her daughter Kiran about the divorce and continue to live with Jibran in the same house. However, they don't share the bedroom. In the meanwhile, Kiran engagement takes place in a rich family. One day Pakeeza informs to Azeem and Naima about her divorce. Naima and Azeem both start to get little worried about her divorce but they are happy too. Especially Azeem is pretty happy because now he has the opportunity to marry with Pakeeza. Pakeeza is little worried about the marriage of her daughter. In the meantime, Pakeeza and Azeem both do nikkah, but they hide their nikkah. Only some close friends of Pakeeza know about it. Now, Pakeeza is the wife of Azeem but she is still living with Jibran in the same house because she wants to stay there till the marriage of her daughter. On the other hand, Jibran doesn't know about the nikkah of Pakeeza. Jibran argues with Pakeeza that divorce doesn't happen in anger. Just three words couldn't separate the relationship of husband and wife.

Pakeeza goes to a lawyer and takes consent of him. The lawyer tells the Pakeeza that after pronouncing three divorces, the relationship between husband and wife come to an end. Now, Pakeeza spends a day in the gallery with Azeem where they pass their time in very happy and romantic mood. Azeem has been shown as a person who takes too much care of Pakeeza and gives her great love. In the night, Pakeeza has to go to Jibran's house just to satisfy her daughter. At last, their daughter Kiran marriage takes place in a rich and decent family. After her marriage, Jibran brings his secretary to his home and spends nights with her in his bedroom. After seeing this, Pakeeza decides to leave the house of Jibran. She then leaves the Jibran's house and finally decides to inform her daughter about her divorce and second marriage with Azeem. In the meanwhile, both Azeem and Pakeeza go to an art exhibition in some other city and heart attack occurs to Pakeeza. She found dead in Azeem's room in the hotel. The police investigate the matter and arrests Azeem for the death of Pakeeza. The media takes the story of her death. Everybody asks the question what Pakeeza was doing in Azeem's room. Azeem tells everyone that Pakeeza was his wife and she had taken divorce from Jibran about few months ago. But nobody come to believe on Azeem. Serious questions rise on the character of Pakeeza. Jibran also denies that he didn't give any divorce to Pakeeza and she was still his wife. Jibran also blames that both Azeem and Pakeeza were living an adultery life. But finally the truth reveal and Kiran find a letter in which Pakeeza has written that she was divorced by Jibran. Now everybody have faith on the innocence of Pakeeza and Jibran has left alone by his daughter and other relatives. 


\section{Analysis of Urdu Drama Pakeeza}

Family destruction and unhealthy relationship appears to be the dominated theme in contemporary Urdu drama serial. Getting love appears to be the old theme, getting exlover through the divorce appears to be new trend in this Urdu drama. The most interested thing in modern drama is the character of Azeem. He has not done the marriage because of Pakeeza, who is mother of young college going girl. It is visible that if husband is harsh and not fulfilling the conjugal rights, then there is no need to worry. After separation, a happy romantic life is waiting for the divorced lady. On the other hand, the reality of life is very different. Research regarding Pakistani society indicates that even a young girl when she takes divorce, nobody willing to marry with her. If somebody willing to marry with a divorce girl, it will be of her father age. If divorce girl has no children, then she has the chance that somebody would accept her and if any divorce lady has children, then it is almost impossible for her to get marry again. But drama depicts that there is no problem even foran aged lady, she could get good husband after the finish of first marriage. So such message might be harmful for the society especially for those ladies who are not living in good relation with their in laws or husband. They might perceive that after getting rid of this marriage, they might find another suitable person which might give them more respect and love, and more cheerful life.

\section{Maan Mayal (Urdu Drama)}

\section{Background of Drama}

Urdu Drama serial Maan Mayal was directed by Haseeb Hassan. The writer of the drama was Samira Fazal. The drama was produced by Momina Duraid, Sana Shanawaz, Samina Humayun and Tariq Shah. Mann Mayal was a romantic drama serial and it was telecasted from Hum TV on every Monday. The drama was on aired in the prime time i.e. from 8.00 $\mathrm{pm}$ to $9.00 \mathrm{pm}$. The drama was consisted of thirty three episodes. The first episode of Mann Mayal was telecasted on January 25, 2016 and the last episode of this serial was broadcasted on September05, 2016. Hamza Ali Abbasi, Maya Ali, Ayesha Khan and Gohar Rasheed were included in the main cast of this drama (Awan, 2016; Azfar, 2016; Sulaiman, 2016). Maan Mayal was having many characters, but here focus will be on three characters which are more related to extramarital relation, so discussion will be made only about concerned characters.

\section{The Setup (Act One)}

In the start, the drama focuses on the two important characters i.e. Manahil a young girl and a young male i.e. Salahuddin who fall in love with each other. Manahil and 
Salahuddin used to live as neighbours. Salahuddin shows as very ambitious about his studies. In the meanwhile, Manahil fails in the Bachelor of Arts examination. Manahil's father request Salahuddin to give tuition to Manahil because of her poor performance in her last examination. This tuition gives both of them a chance to come close to each other. During their tuition period, both fall in love with each other. Manahil belongs to a rich family but Salahuddin belongs to a lower middle class family. Salahuddin has little bit complex of his poor status. He thinks that there is difference of social class status between him and Manahil. He also feels that her marriage proposal might be rejected by the family of Manahil so he refuses to marry with Manahil. The parents of Salahuddin are also afraid of this relation because they think that their proposal would be rejected by theparents of Manahil.

On the other hand, Manahil wants to marry with Salahuddin but he doesn't agree on this. This part looks to be little confusing for audience that both hero and heroine who love with each other and their families are also willing to accept their proposal. But Salahuddin thinks that he doesn't meet the status of Manahil's family, so he finally rejects the idea of marriage with Manahil. The decision of rejection by Salahuddin without any strong reason seems to be quite astonishing that somebody is rejecting his lover because he think that she will not be comfortable with him in the future due to different social status. So Manahil's family accepts the proposal of another guy named Mikaael. Mikaael is the only son of his parents who also belongs to a rich family. Accordingly, the love story of Salahuddin and Manahil ends at the start of the drama after the marriage of Manahil with Mikaael.

\begin{tabular}{|l|l|}
\hline Character's Name & Character's Explanation \\
\hline Manahil & $\begin{array}{l}\text { A young girl who loves with a guy but later on she marries } \\
\text { with another person }\end{array}$ \\
\hline Salahuddin & A young man who loves Manahil \\
\hline Mikaael & Husband of Manahil with an arrogant personality \\
\hline
\end{tabular}

\section{The Conflict (Second Act)}

Manahil's family used to live in Lahore. But her in-laws used to live in Karachi, so after her marriage she shifter from Lahore to Karachi. On the other hand, her ex-lover Salahuddin also gets a job in Karachi, so he also shifts from Lahore to Karachi. Mikaael is very impolite and careless guy who has done his marriage just for the sake of his parents. He does not treat Manahil in a good manner. He spends most of the time outside the house and especially he is habitual of attending the late night parties and also fond of gambling. Manahil tries to change herself according to the wishes of her husband. She changes her eastern dresses and also cuts her hair to become an adoptable person for her 
husband Mikaael. All these efforts of Manahil make no impact on her husband. He continues to behave unsympathetic and uncaring with Manahil.

One day Salahuddin calls to his sister who tells him that Manahil is not living a happy life at his home. Her husband doesn't care about her and their marriage life could come to an end. This provokes new hope in the mind of the Salahuddin to get Manahil. On the other hand, Manahil doesn't think about her past. Though she remembers Salahuddin but she adopts the harsh reality of her marriage life. One day, when Manahil goes to her parent's home, Salahuddin meets her there and tries to convince her that she should get rid of Mikaael and also they could start a new life. Manahil refuses him and reminds him that he is the same person who rejected her because of her higher social status.

Salahuddin works hard and becomes a rich person. The time passes and Manahil becomes the mother of two children. Salahuddin doesn't marry yet and still he hopes to get Manahil. In the meanwhile, Salahuddin places one of his servants in the house of Manahil just to know that what is going in the life of Manahil. The servant Jameel gives each and every update about Manahil and her family to Salahuddin. Jameel also tells Manahil that he has a teacher who is an intellectual person and he always takes advice from him. In this way, Jameel develops a contact between Manahil and Salahuddin. Manahil doesn't know that the teacher of Jameel is Salahuddin. Whenever she faces some problems, she takes an opinion from Salahuddin through short messaging service. So the link develops between Salahuddin and Manahil. But this contact finishes after sometime when Manahil come to know the reality. In the meanwhile, a girl enters in the life of Salahuddin i.e. Jeena who has been depicted as alone and works in the office of Salahuddin.

Jeena falls in the love with Salahuddin and wants to marry with him but Salahuddin is not willing to marry with her as he is waiting only for Manahil. Jeena eventually knows about Salahuddin and Manahil relations. On the other hand, Mikaael looses all his property and assets in gambling. Manahil tries to convince him that he should leave gambling but Mikaael takes all the jewellery and property assets of Manahil and pushes her out of the home. Thus, Manahil leaves Mikaael's home with her two children. She goes to railway station to go to her parent's home but she finds that she doesn't have enough money to reach Lahore. So she takes help from ex-servant Jameel which brings her to theservant quarter of Salahuddin's home. Salahuddin asks Manahil that instead of going to parent's home, it is better for her to talk with Mikaael. Accordingly, they both go to the Mikaael's home. When Mikaael sees Salahuddin and Manahil together so he becomes harsher and finally gives divorce to Manahil. 


\section{Resolution (Third Act)}

After the divorce, Manahil comes to Salahuddin's home. The mother of Manahil calls Salahuddin and asks him to keep Manahil at his home. Because Manahil's father is very ill so she shouldn't come back to her parent's home. In the meanwhile, Manahil tells her mother that Mikaael has given her divorce. Manahil's mother still insists her to stay at Salahuddin's home because her father is cardiac patient and he couldn't bear the news of her divorce. Manahil used to live at Salahuddin's home. This gives another chance to Salahuddin to come close to Manahil and to convince her about her love but Manahil shows anger over Salahuddin. On the other hand, the secretary of Salahuddin i.e. Jeena also worries about Manahil's presence at Salahuddin's home. Subsequently, she tries to create distance among both of them. Even though, Salahuddin fully focuses on Manahil to grab her attention. Manahil wants to go to her parent's home as quickly as possible but her family members force her to stay there. Butat last, Manahil goes to her parent's home with Salahuddin to see her father and after that, both return to Karachi.

In the meantime, parents of Salahuddin don't like the presence of Manahil at their home. Especially, Salahuddin's mother doesn't like that her son might marry with a mother of two children. But Salahuddin doesn't want to leave Manahil and he shows too much care and respect towards Manahil and her children. The father of Salahuddin also doesn't happy with his son. He thinks that Manahil and Salahuddin have fallen in adult relation and due to this, Salahuddin doesn't give attention to Jeena. They also start to get worried that their son is leaning towards a divorced woman who is also having two children. The mother of Salahuddin starts maltreating of Manahil just to show that he has no values for Manahil. This attitude makes Salahuddin more rigid and he feels more sympathy for Manahil. Salahuddin finally decides that he should marry with Manahil. He informs Jeena that he will not marry with her and Manahil would be his wife.

This decision makes Jeena more annoyed and she begs from him for not to leave her but Salahuddin doesn't agree. Now Jeena thinks to take revenge from Salahuddin and Manahil. After the breakup of engagement of Salahuddin and Jeena, the parents of Salahuddin also change their attitude toward Manahil. When Manahil come to know that Salahuddin has broken his engagement, she becomes angry over Salahuddin and tells him that she will not marry with Salahuddin. With the passage of time, both Manahil and Salahuddin show in very light mood. And the parents of Salahuddin also give more attention to Manahil. Salahuddin finally tells her mother that he wants to marry with Manahil but his mother insists that he shouldn't marry with a divorced girl. Salahuddin insists that he will not leave Manahil at any cost because God has given him this opportunity. He tells his mother that he will not lose this opportunity. In the meanwhile, Jeena takes her revenge and she mixes the poison in the juice to kill Manahil and her children. But instead of Manahil, Salahuddin takes the juice and truth reveals that Jeena 
has mixed the poison in the juice. This incident brings Manahil and Salahuddin to come close to each other. Finally, Salahuddin convince his parents to marry with Manahil andthe drama ends with the marriage of both Manahil and Salahuddin.

\section{Analysis of Urdu Drama Maan Mayal}

In this drama serial, strange thing has been depicted. The hero Salahuddin rejects her lover at the start without any solid reason. He thinks that he is from middle class family so he would not be able to keep Manahil happy. After the marriage of Manahil with Mikaael, Salahuddin thinks that he has made a wrong decision. Now he starts interfering in the life of married Manahil. Salahuddin places one of his servants in the house of Manahil just to know about her life problems. In this manner, the servant links a relation between the ex-lovers. Whenever Manahil needs some help, she requests to her ex-lover. Also, Salahuddin didn't marry after the marriage of Manahil and he continues to wait for her. The message depicted in this drama serial is that in case of cruel husband or negative relation with spouse, the protagonist will be ex-lover who will continue to help that married girl and will ultimately rescue her. Another stereotypical thing happened in Maan Mayal that when Manahil is divorced by her husband, she decided to go to her family but her mother didn't give her positive response due to the illness of her father. Even Manahil's mother suggested her to stay at the home of Salahuddin. It seems to be quite amazing that mother is not allowing her daughter to come back to home instead she asks her to stay with her ex-lover. At the end, Salahuddin marries with Manahil and also accept her two kids.

Unhealthy communication, negative relationship and divorce between the spouses seem to be the ultimate objectives of the drama and regaining of ex-lover appears to be the target of contemporary Urdu dramas. Instead of focusing on the social and family values, the major objectives of the drama producers give the impression for getting highest TRP. Rather concentrating on the real problems of the society, commercialism appears to be the vital purpose of modern Urdu dramas.

\section{Conclusions}

The analyses revealed that both these selected dramas depicted that wife is shown occupied in extra marital relation. In Urdu Drama Pakeeza, heroine of the drama was shown to be involved with another man because her husband is depicted as cruel and harsh. The attitude of her husband provided a force to wife to lean towards another man. In drama serial Maan Mayal, the husband of the heroine is shown to be fond of gambling as well as a careless person. Again, the attitude of husband provided a reason to wife to lean towards another person. Both of these dramas depicted that woman must need a man in all the times. She could only survive in this world if she has the affiliation with a man. 
Though, first husband is depicted as harsh and cruel but even then she needs the help of any other male to get rid of the cruelty of husband. Through the gender lens, it is being depicted that woman couldn't survive in this society without the help of males.

The current study observes that the wife tilted towards another person only because of her partner's attitude, so this attitude forced the wife to develop an extramarital relation with another person. The current research reveals that man who is involved with married wife is shown to be very gentle, loving, and principled person. Both dramas end up with divorce and also with the second marriage of involved wives in extramarital relations. The married heroines not only become successful in getting rid of their cruel husbands but this success is only possible with the help of another man, which shows that women by their own cannot get rid from the cruel husband.

Luckily, both lovers were waiting for married ladies for almost one or two decades. These lovers also continue to provide help to these married heroines even during their married life. The portrayal of such stories indicate that media is promoting the extramarital relations. These Urdu dramas also show no room for reconciliation between the married spouses. Divorce and second marriage is shown to be the only solution to get rid of wicked husband. All these dramas indicate that women are helpless victim of the society. The problems between the spouses can't be ignored but it doesn't mean that media should present the spouse quarrel in such a way that divorce seems to be the only solution of the problems. Infact, divorce is no longer depicted as a social evil but it is almost as if it is being promoted.

The main themes which emerge from these dramas serials are:

1. Life partner is not good one (husband). They are cruel, it is impossible to live with them.

2. A third person is waiting for the breakup of marriage who also assures to married lady that a lovely romantic life is waiting for them.

3. Wife does need the help of somebody to get rid from her marriage.

4. Man is being depicted as an important gradient of woman's life and if they get rid from the first one, they must need another man to continue their life.

\section{Realities of Pakistani Society}

The reality of Pakistani society is much different from that the portrayal of television soap operas. In a Pakistani society, it is very difficult to find a suitable proposal for any divorced lady. Moreover, if she is a mother of any child, then it almost looks impossible for the divorced lady even to find an inappropriate match. But on the other hand, the media of Pakistan is depicting that a lovely romantic life is waiting for her with the second husband. Chowdhry (2013)highlighted the problems of the divorced women in Pakistani society. She argued, "The stigma of divorce also means women find it hard to remarry, and many feel it's easier to stay in an unhappy marriage than be alone. The 
difficulties multiply when children are involved." This explains the real picture of Pakistani society which is totally contrasted to the picture that is being depicted in the entertainment media of Pakistan.

Kamal (2012)also explains the same problems that it is almost impossible to remarry for a girl with a single child. A women Tanya who was divorced about ten years ago reveals the same story. "I get proposals from men who are either drawn by my family's wealth and are seeking to establish themselves or else want me to leave my daughter with my parents" says Tanya. But on the other hand, her husband had been remarried with another young lady within six months of their divorce. Kamal also inquired from one of the top matrimonial services of Karachi city about the second marriage of divorced men and women. The owner of the matrimonial office told her that normally divorced male find a suitable demanded match but this luxury is not available to divorced or widow women. Simply, a divorcee woman has to compromise on the man's age, financial position, education and physical appearance as well as being willing to take on the responsibility of his offspring. But the media of Pakistan are not highlighting these problems in their entertainment drama serials. The drama production companies and producers are simply encouraging the married women to get rid of their first marriage and also portraying that a happy second marriage is waiting for them.

\section{Recommendations}

- This study was limited to narrative structure analysis. To analyze the effects or impact of these dramas on the society's behaviour, future researchers should conduct cross-sectional survey research to gather data regarding the social life of the target audience.

- The future studies could be done through the technique of content analysis of these Urdu televised soap operas. The content analysis could also provide the generalizability of the current result.

\section{References}

Ahmed, A. (2005). Arz-e-Musanif. Lahore: Sang-e-Meel Publications.

Ahmed, A. (2012). Women and Soap-Operas: Popularity, Portrayal and Perception. International Journal of Scientific and Research Publications, vol.2:6, pp.1-6.

Al Helal, M. A. (2013). Toward the Impacts of Indian Drama Serials on Bangladeshi Family System: An Overview of People's Perception. Journal of Social Sciences and Humanities, vol.8:2, pp.24-34. 
Ali, R. N. (2016). Pakeezah on Hum TV. (2018, July 12). Retrieved from https://reviewit.pk/pakeezah-\%D9\%BE\%D8\%A7\%DA\%A9\%DB\%8C\%D8\%B2 $\% \mathrm{DB} \% 81$-on-hum-tv/

Allen, R. C. (1995). Introduction. In R. C. Allen (Ed.), To Be Continued--: Soap Operas Around the World (1st ed., pp. 1-26). Oxon: Routledge.

Awan, F. (2016). Mann Mayal - Episode 1. (2018, July 25). Retrieved from https://reviewit.pk/mann-mayal-episode-1/

Azfar, S. (2016). Get Ready for Mann Mayal in 2 Days. (2018, July 18). Retrieved from https://www.hipinpakistan.com/news/1148876/get-ready-for-mann-mayal-in-2days/print

Berger, P. L., \& Luckmann, T. (1991). The Social Construction of Reality: A Treatise in the Sociology of Knowledge. New York: Penguin Books.

Birch, A. (2014). Aristotle's Elements of Drama. (2018, May 15). Retrieved from http://www.mindtools.net/MindFilmsristot.shtml

Birch, A. (2018). Aristotle's Six Elements of Drama. (2019, January 15). Retrieved from https://mindtools.net/2018/11/23/aristotles-six-elements-of-drama/

Bordwell, D. (2008). Three Dimensions of Film Narrative. In D. Bordwell (Ed.), Poetics of Cinema (pp. 85-134). New York: Routledge.

Brown, W. J. \& Singhal, A. (1993). Ethical Considerations of Promoting Prosocial Messages Through the Popular Media. Journal of Popular Film and Television, vol.21:3, pp.92-99.

Chong, A. \& Ferrara, E. L. (2009). Television and Divorce: Evidence from Brazilian Novelas. Journal of the European Economic Association, vol.7:2-3, pp.458-468.

Chowdhry, A. (2013). Pakistani Women Turn to Once-Taboo Divorce to Escape Abuse. (2018, August 28). Retrieved from https://www.reuters.com/article/us-pakistandivorce/pakistani-women-turn-to-once-taboo-divorce-to-escape-abuseidUSBRE90806J20130109

Comstock, J. \& Strzyzewski, K. (1990). Interpersonal Interaction on Television: Family Conflict and Jealousy on Primetime. Journal of Broadcasting \& Electronic Media, vol.34:3, pp.263-282. 
Dainow, B. (2014). Frankfurt Meets Holywood: Adorno and Horkheimer's "The Culture Industry". National University of Ireland. Maynooth.

Douglas, W. \& Olson, B. M. (1995). Beyond Family Structure: The Family in Domestic Comedy. Journal of Broadcasting \& Electronic Media, vol.39:2, pp.236-261.

Farooq, U. (2016). Cast \& Crew: Hum TV Drama Serial Pakeeza. (2018, July 16). Retrieved from https://www.ebuzztoday.com/cast-crew-hum-tv-drama-serialpakeeza/

Haider, S. \& Siddique, S. (2015). Do Modern Pakistani TV Romances Fall Short of Classics Like Dhoop Kinarey? (2018, June 04). Retrieved from https://www.dawn.com/news/1195486

Iwuchukwu, O. (Ed.) (2008). Elements of Drama (Vol. 2008). Lagos: National Open University of Nigeria.

Johnson, K. R. \& Holmes, B. M. (2009). Contradictory Messages: A Content Analysis of Hollywood-Produced Romantic Comedy Feature Films. Communication Quarterly, vol.57:3, pp.352-373.

Kamal, R. (2012). Shaadi 2.0. (2018, August 29). Retrieved from https://tribune.com.pk/story/379627/shaadi-2-0/

Khan, S. (2016). Episodes 1 and 2 of 'Pakeezah' are a Breath of Fresh Air. (2018, July 15). Retrieved from https://www.hipinpakistan.com/news/1149098

Modleski, T. (1979). The Search for Tomorrow in Today's Soap Operas: Notes on a Feminine Narrative Form. Film Quarterly, vol.33:1, pp.12-21.

Prisyazhnyuk, T. \& Zilova, E. (2014). Media Discourse in the Context of Values Study. Paper presented at the CBU International Conference Proceedings.

Rehman, S. I. U., Arafat, Y., Sial, N. \& Shah, B. H. (2019). Framing of Urdu Drama Serials: From Social Religious Values to Family Catastrophe. Al-Qalam, vol.23:2, pp.44-67.

Siddique, S. (2016). 'No Means Yes': Pakistan TV's Dangerous Trend of Celebrating Rapists and Stalkers as Heroes. (2018, June 02). Retrieved from 
https://tribune.com.pk/story/1082725/no-means-yes-pakistan-tvs-dangeroustrend-of-celebrating-rapists-and-stalkers-as-heroes/

Sulaiman, G. (2016). Mann Mayal Drama OST, Timings \& Pictures. (2018, July 26). Retrieved from https://www.brandsynario.com/hum-tvs-drama-mann-mayal-osttimings-pictures/

Tahir, M. (2009). Television Kay Urdu Dramay. Lahore.

Taylor, E. (1989). Prime-Time Families: Television Culture in Post-War America. Oakland: University of California Press.

Üçer, N. (2013). Creation of a "Virtual World" via Soap Opera: Analysis of the Valley of the Wolves and Associated Coverage in Hurriyet and Milliyet Newspapers. Global Media Journal: Turkish Edition, vol.3:6, pp.213-229.

Wali, K. (2014). Losing Our Culture and Identity, One Drama at a Time. (2018, July 04). Retrieved from http://blogs.tribune.com.pk/story/20620/pakistani-dramas-losingour-culture-and-identity-one-drama-at-a-time/

Zare, B. (2001). Sentimentalized Adultery: The Film Industry's Next Step in Consumerism? The Journal of Popular Culture, vol.35:3, pp.29-41.

Yasar Arafat is Research Associate and Ph.D Scholar in the Department of Media and Communication Studies, International Islamic University Islamabad (IIUI).

Nauman Sial is Research Associate and Ph.D Scholar in the Department of Media and Communication Studies, International Islamic University Islamabad (IIUI).

Abid Zafar is Researcher in the Department of Media and Communication Studies, International Islamic University Islamabad (IIUI). 